\title{
Autoreactive T-Lymphocytes in Inflammatory Skin Diseases
}

\author{
Wolf-Henning Boehncke ${ }^{1,2 \star}$ and Nicolo Costantino Brembilla ${ }^{1}$ \\ ${ }^{1}$ Department of Pathology and Immunology, Faculty of Medicine, University of Geneva, Geneva, Switzerland, ${ }^{2}$ Divison of \\ Dermatology and Venereology, Geneva University Hospitals, Geneva, Switzerland
}

The presence of one or several autoantigen(s) and a response by the adaptive immune system are the key criteria to classify a pathology as an autoimmune disease. The list of entities fulfilling this criterion is currently growing in the light of recent advancements in the pathogenetic understanding of a number of important dermatoses. The role of autoreactive T-lymphocytes differs amongst these pathologies. While they are directly involved as effector cells attacking and sometimes killing their respective target in some diseases (e.g., vitiligo), they provide help to B-lymphocytes, which in turn produce the pathogenic autoreactive antibodies in others (pemphigus and pemphigoid). Atopic dermatits is a chimera in this regard, as there is evidence for both functions. Psoriasis

OPEN ACCESS

Edited by: Katja Bieber,

Universität zu Lübeck, Germany

Reviewed by:

Kentaro Izumi,

Hokkaido University, Japan Andras Perl,

Upstate Medical University, United States

Christoph M. Hammers,

Universität zu Lübeck, Germany

*Correspondence:

Wolf-Henning Boehncke wolf-henning.boehncke@hcuge.ch

Specialty section:

This article was submitted to Autoimmune and Autoinflammatory

Disorders,

a section of the journal

Frontiers in Immunology

Received: 01 March 2019 Accepted: 13 May 2019

Published: 29 May 2019

Citation:

Boehncke W-H and Brembilla NC (2019) Autoreactive T-Lymphocytes in

Inflammatory Skin Diseases.

Front. Immunol. 10:1198.

doi: 10.3389/fimmu.2019.01198 is an example for an entity where autoantigens were finally identified, suggesting that at least a subgroup of patients should be classified as suffering from a true autoimmune rather than autoinflammatory condition. Identification of resident memory T-lymphocytes $\left(\mathrm{T}_{\mathrm{RM}}\right)$ helped to understand why certain diseases relapse at the same site after seemingly effective therapy. Therefore, the in-depth characterization of autoreactive T-lyphocytes goes way beyond an academic exercise and opens the door toward improved therapies yielding durable responses. TRM are particularly suitable targets in this regard, and the clinical efficacy of some established and emerging therapeutic strategies such as the inhibition of Janus Kinase 3 or interleukin 15 may rely on their capacity to prevent $T_{\text {RM }}$ differentiation and maintenance. Research in this field brings us closer to the ultimate goal in the management of autoimmunity at large, namely resetting the immune system in order to restore the state of tolerance.

Keywords: resident memory T-lymphocytes, psoriasis, atopic dermatitis, bullous pemphigoid, pemphigus, alopecia areata, vitiligo, scleroderma

\section{INTRODUCTION}

During T-cell development, T-cell receptors (TCR) are generated randomly and subsequently undergo a selection process in the thymus (Figure 1). This includes a positive round of selection to guarantee selfMHC-restriction and a negative round to eliminate T-cells that recognize selfantigens too strongly. The fate of a developing T-cell depends on the strength and duration of the interaction between its TCR on the one hand and the self-peptide-MHC complexes presented by thymic cells on the other hand. While TCRs with theoretically infinitive affinity may be generated, developing T-cells have to match a binary destiny: life or death. The intrinsic mechanism of selection is thus prone to the development of auto-reactive cells, especially those harboring TCRs with affinity close to the threshold for negative selection (1). Another issue comprises the 




FIGURE 1 | Shaping the T-cell repertoire. T-lymphocytes undergo positive selection to ensure restriction to the host's antigen presenting molecules as well as negative selection to eliminate strongly autoreactive cells in the thymus prior to populating the periphery. T-cells whose TCR affinity is close to the threshold for negative selection have a high potential for autoreactivity and escape thymic negative selection. A subset of these cells is programmed to become Treg cells, others (the potentially pathogeneic autoreactive cells) are kept under the control of the peripheral tolerance.

presence of tissue-specific genes that are not expressed in the thymus and poorly regulated by the autoimmune regulator [AIRE, (2)], toward which T-cells are not depleted during thymic selection. As a result of these mechanisms, autoreactive $\mathrm{T}$-cells are released into the circulation and inevitably exist in all individuals (3). Autoreactive T-lymphocytes behave just like "normal" ones, namely, they recognize antigenic peptides presented to them in the context of a host's antigen presenting HLA molecule and become activated if the appropriate signals are provided. The difference lies in the antigenic peptide, which for "normal" T-lymphocytes is a foreign structure, e.g., part of a pathogen, while autoreactive T-lymphocytes are specific for peptides representing "self," e.g., part of an anchoring protein of keratinocytes.

The autoreactive compartment comprises at least two types of cells: self-reactive cells programmed during development to control the immune response as a part of a peripheral tolerance mechanism (this is the case for regulatory T-cells, $\mathrm{T}_{\text {regs }}$ ), and autoreactive cells that may turn to be harmful and cause autoimmunity. The latter are, however, found at low frequencies in the peripheral T-cell pool, and their functions are hidden by peripheral tolerance mechanisms. Harmful autoreactive T-cells that escape central tolerance are indeed rendered inoffensive via anergy, ignorance, and active suppression by $\mathrm{T}_{\text {regs }}$ [reviewed in (4)].

$\mathrm{T}_{\text {regs }}$ can be classified into thymic $\mathrm{T}_{\text {regs }}$, peripheral $\mathrm{T}_{\text {regs }}$, and in vitro induced $\mathrm{T}_{\text {regs }}$ (5). These subsets show functional and phenotypic similarities, but differ epigenetically. $\mathrm{T}_{\text {regs }}$ interact directly with different cell types of the innate and adaptive immune systems, but also exhibit their anti-inflamamtory effects via cytokines such as IL-10, IL-35, TGF- $\beta$, and galectin- 1 .

The frequency of autoreactive T-cells specific for a given selfantigen has been evaluated by peptide-MHC tetramer technology to be similar to those specific for foreign antigens, in the order of 1 to 10 per million T-cells (6). The study of the total autoreactive T-cell repertoire in healthy individuals is, however, hampered by the fact that peripheral tolerance mechanisms make autoreactive T-cells functionally indistinguishable. Richards and colleagues addressed this issue by analyzing the "exposed" self-reactive Tcells upon removal of $\mathrm{T}_{\text {reg }}$ cells in Foxp $3^{\text {DTR }}$ mice. Self-reactivity was observed in about $4 \%$ of peripheral CD4+ and CD8+ T-cells, a frequency similar to the responses to allo-MHC complexes or superantigens (7).

Thus, autoreactive T-cells are readily detectable in healthy individuals, but they are efficiently controlled by peripheral tolerance. When the tolerance is broken, autoreactive T-cells 
TABLE 1 | The role of autoreactive T-lymphocytes in inflammatory skin diseases.

\begin{tabular}{|c|c|c|c|}
\hline Entity & $\begin{array}{l}\text { HLA } \\
\text { association }\end{array}$ & autoantigen & T-cell involvement \\
\hline Vitiligo & Yes & $\begin{array}{l}\text { Melanocyte-dervied } \\
\text { antigens }\end{array}$ & $\begin{array}{l}\text { - } \text { CD8+, destroying } \\
\text { melanocytes } \\
\text { - } \mathrm{T}_{\mathrm{RM}}\end{array}$ \\
\hline Alopecia areata & Yes & $\begin{array}{l}\text { - Trichohyalin? } \\
\text { - Tyrosinase- } \\
\text { related protein-2 }\end{array}$ & $\begin{array}{l}- \text { CD8 } \\
\text { - (CD4+ needed in } \\
\text { animal models for } \\
\text { maximal induction) }\end{array}$ \\
\hline Psoriasis & Yes & $\begin{array}{l}\text { - } \text { ADAMTS-like protein } \\
\quad 5 \\
\text { - (LL-37) } \\
\text { - (neolipid antigens) }\end{array}$ & $\begin{array}{l}\text { - } \mathrm{CD} 8+ \\
\text { - } \mathrm{T}_{\mathrm{RM}}\end{array}$ \\
\hline Scleroderma & Yes & $\begin{array}{l}\text { Unknown (Nuclear } \\
\text { antigens (Topo1, } \\
\text { RNApollll, centromere) } \\
\text { recognized by } \\
\text { autoantibodies) }\end{array}$ & - $\mathrm{CD} 4+, \mathrm{CD} 8+$ \\
\hline $\begin{array}{l}\text { Bullous } \\
\text { pemphigoid }\end{array}$ & Yes & $\begin{array}{l}\text { NC16A domain of } \\
\text { BP180 }\end{array}$ & $\mathrm{CD} 4+$ \\
\hline $\begin{array}{l}\text { Pemphigus } \\
\text { vulgaris }\end{array}$ & Yes & Desmoglein 3 & CD4+ \\
\hline Atopic dermatitis & No & Hom s 2 ( $\alpha$-NAC) & $\begin{array}{l}\text { CD8+, producing IL-4 } \\
\text { and IFN- } \gamma\end{array}$ \\
\hline
\end{tabular}

may become activated and generate overt autoimmunity. In that regard, interesting insights are being generated by the therapeutical use of checkpoint inhibitors, e.g., CTLA-4 and programmed cell death protein 1 (PD-1) blocking antibodies. These compounds represent a promising approach to treat various cancers since they boost specific anti-tumor T-cell immunity by restraining tolerogenic mechanisms exploited by the tumor. The drawback is that peripheral tolerance is weakened and patients may develop so called immune-related adverse events (irAEs). These irAEs differ from "classic" organ-specific autoimmune disease in as much as they affect a broader range of organs and cells (8). These data clearly show how autoreactive T-cells may be reactivated in particular situations.

How tolerance is broken or evaded during "classical" autoimmunity is a complex and incompletely understood matter. Autoimmune responses are currently thought to arise from a combination of genetic and environmental factors. For example, HLA polymorphisms could result in altered regulation or reduced threshold for autoreactive T-cells, with environmental factors constituting the initial triggering for inappropriate activation (9). Regarding peripheral tolerance, $\mathrm{T}_{\text {regs }}$ may become dysfunctional through at least 4 distinct mechanisms, namely plasticity (capacity to produce IL-17 after loss of the transcription factor FOXP3), reduced CD18 expression, epigenetic changes, and inhibitory mRNA targeting FOXP3. This allows proinflammatory cells such as Th1 and TH17 lymphocytes to escape regulation and to perform their effector functions in an uncontrolled manner (10).

Activation of autoreactive T-lymphocytes is a key event in almost any kind of autoimmune response: while T-cells are important effectors in some entities (e.g., psoriasis), their principal mode of action in other diseases is to provide help for
B-lymphocytes produce the disease-mediating auto-antibodies (e.g., bullous pemphigoid). A clinical consequence is that drugs targeting T-cell function are highly effective to treat the former, while B-cell directed drugs currently represent the gold standard for the latter.

We will now discuss the current pathophysiological concepts of the clinically most relevant inflammatory skin diseases for which a role of autoreactive T-lymphocytes is either wellestablished or suggested based on the evidence.

\section{VITILIGO}

Vitiligo (11) (Table 1) occurs in about 1\% of the population worldwide and is thus the most common cause of acquired skin, hair, and oral depigmentation. It is characterized by the occurence of well-demarked whitish macules. The histology of lesional skin is characterized by a dermal inflammatory infiltrate along with hypopigmentation in the basal layer of the epidermis, the latter being caused by destruction of melanocytes. The hypothesis of it representing a T-cell mediated autoimmune disease is backed up by its HLA association, the identification of melanocyte-derived potential autoantigens $(12,13)$, and demonstration of CD8+ T-lymphocytes targeting and destroying melanocytes (14). Consequently, most of the strategies used to treat vitiligo have an impact on T-cell function. This holds true for topical glucocorticosteroids and calcineurin inhibitors as well as phototherapies, while the use of other systemic immunosuppressants is not recommended based on current guidelines (15).

Frequently, rapid recurrences at identical locations are observed after stopping therapy (16), arguing in favor of a persisting cutaneous autoimmune memory, which reactivates the disease once the treatment has been stopped. Resident memory T-lymphocytes $\left(\mathrm{T}_{\mathrm{RM}}\right)$ are candidates representing this memory (17), and several groups have described their presence in vitiligo (18-20). Efforts to provide evidence in favor of their direct pathogenetic involvement are hampered, as there are currently no tools at disposition that allow for their specific removal or blockade without affecting other T-cell populations. Recently, Richmond et al. confirmed the $\mathrm{T}_{\mathrm{RM}}$ phenotype of autoreactive T-lymphocytes within lesions of vitiligo patients (21). Using a mouse model, they went on to demonstrate that blocking the receptor for interleukin-15 (IL-15) - a crucial cytokine for $\mathrm{T}_{\mathrm{RM}}$ generation and function-with a specific antibody reverses the disease and depletes $\mathrm{T}_{\mathrm{RM}}$ after longterm therapy. Interestingly, even short-term local intradermal treatment provided durable repigmentation without depletion of autoreactive T-lymphocytes. Taken together, the authors suggest that autoreactive T-lymphcytes are recruited to the skin, encounter IL-15 presented to them by keratinocytes, up-regulate interferon gamma (IFN- $\gamma$ ), and depend on IL-15 for survival once they become resident in the epidermis.

\section{ALOPECIA AREATA}

Alopecia areata (AA) (22) (Table 1) has a cumulative lifetime incidence of about $2 \%$. It manifests in the form of non-scarring, 
patchy hair loss, with a narrowing of the hair shaft near the scalp as a hallmark. Histology reveals a peribulbar lymphocytic infiltrate, comprising CD8+ T-lymphocytes within the follicular epithelium, and CD4+ T-lymphocytes around the hair follicules. Evidence in favor of an autoimmune pathogenesis comes from its HLA association (23), association with other autoimmune diseases such as vitiligo (24), and response to immunosupressive therapies (25).

Similar to the central nervous system or the placenta, the hair follicule is considered an immune privileged site. Evidence in favor of this hypothesis comes from experiments showing survival of melanocytes in hair follicules grafted from black guinea pig skin onto albino guinea pigs, and viability of human dermal sheath tissues within sex-mismatched transplants (26, 27). It is the loss of this immune privilege that is considered a cornerstone in the pathogenesis of AA. The mechanisms of immune privilege preservation in hair follicles as well as potential causes of its collapse have recently been reviewed elsewhere (28).

Several lines of evidence, including elegant experiments using human scalp explants grafted onto severely immunocompromised mice, point toward CD8+ T-lymphocytes as important effector cells. However, maximal induction of the AA phenotype requires the help of $\mathrm{CD} 4+\mathrm{T}$-lymphocytes $(29,30)$ Using a well-established $\mathrm{C} 3 \mathrm{H} / \mathrm{HeJ}$ mouse model (31), characterized by spontaneous development of alopecia and recapitulating many pathologic features of human AA, Xing et al. identified a subset of cytotoxic memory Tlymphocytes (CD8+NKG2D+) as the relevant effector cells for the autoimmune response toward the hair follicle, and postulated that IFN- $\gamma$ secreted from CD8+ T-lymphocytes erases the immune priviledge in the hair follicle, inducing the production of IL-15 and promoting further cellular autoimmunity (32). This hypothesis is strikingly similar to the current pathogenic concept in vitiligo (see above).

Progress toward identifying putative autoantigens in AA was made using a two-step screening approach: first, candidate peptides derived from proteins expressed by keratinocytes or melanocytes (as the suspected targets of autoreactive Tlymphjocytes) were designed in silico based on their affinity to the AA-associated allele HLA-A*0201. These were then screened for their capacity to activate CD8+ T-lymphocytes from AA patients. Using this approach, the hair follicle antigens trichohyalin and tyrosinase-related protein- 2 were identified as putative autoantigens, with trichohyalin being capable of inducing mononuclear cells to secrete proapoptotic factors harmful to hair follicle keratinocytes (33).

\section{PSORIASIS}

Psoriasis (34) (Table 1) affects around 2\% of the population. The characteristic red scaly plaques, which often occur on elbows, knees, and scalp, but can affect any site of the body, already highlight the two major pathogenetic processes active in parallel in psoriasis, namely inflammation (explaining the redness) and epidermal hyperproliferation (hence the scaly plaque). This is histologically reflected by epidermal acanthosis (thickening of viable layers), hyperkeratosis (thickened cornified layer), and parakeratosis (cell nuclei present in the cornified layer). Rete ridges reach deep into the papillary dermis, resulting in profound indentation of both layers. Within the dermis, blood vessels are dilated, contorted, and reach into the tips of the dermal papillae. Finally, there is a mixed epidermo-dermal mononuclear inflammatory infiltrate rich in T-lymphocytes, along with increased numbers of macrophages, mast cells and neutrophils. The epidermal accumulation of the latter results in the so-called pustules of Kogoj and subcorneal microabscesses (Munro's microabscesses).

Ever since the introduction of ciclosporine $\mathrm{A}$ into the therapeutic armentarium, psoriasis has been regarded as a Tcell driven disease, and the important role of T-lymphocytes triggering psoriasis has been shown using $\mathrm{T}$-cell transfer experiments in a xenogeneic transplantation model (35). The observation by Boyman et al. that skin grafts from non-lesional skin of psoriasis patients transferred onto immunodeficient mice spontaneously developed the phenotype of lesional skin was taken as evidence for the presence of $\mathrm{T}_{\mathrm{RM}}$ (36). A clinical study evaluating E-selectin blockade as a means to prevent the extravazation of T-lymphocytes into the skin showed little therapeutic efficacy in treating psoriasis (37). This was taken as evidence that psoriasis depends primarily on skin resident Tlymphocytes rather than recirculating T-lymphocytes. On the other hand, inhibiting CD8+ T-cell migration into the epidermis blocked the psoriatic transformation of the grafts in the model used by Boyman et al. (38), and the blockade of LFA-1, another adhesion molecule involved in T-cell trafficking into the skin, does show clinical efficacy (39). The discrepancy between the two clinical studies cited here may be explained by the complexity of the interplay of adhesion molecules as well as mediators in the recruitment of lymphocytes into the skin (40). Whether or not interference with lymphocyte recruitment to the skin has a therapeutic efficacy, it may thus depend on the exact molecular target(s) as well as the degree to which functional inhibition of a given adhesion molecule is achieved in vivo. The abovementioned observations support the idea of ongoing psoriasis exhausting the pool of skin-resident pathogenic T-lymphocytes and requiring substitution from lymphoid organs, where these clones might reside as central memory T-lymphocytes (41).

HLA association, namely with HLA class I $(42,43)$, and the oligoclonality of the T-cell infiltrate (44) have been interpreted as evidence for an antigen-driven, possibly autoimmune pathogenesis. To date, HLA-C* $06: 02$ is considered the most important psoriasis risk allele (45). In a series of elegant experiments, Arakawa et al. set out to identify potential autoantigens (46). First, they identified HLA-C* $06: 02$ expressing melanocytes as targets for T-cell hybridomas expressing a receptor, which was previously identified as being functionally relevant in patients. They went on to identify the melanocyte ADAMTS-like protein 5 as putative autoantigen and observed T-lymphocytes attacking melanocytes in psoriasis lesions of patients.

Another potential autoantigen LL-37 is generated by extracellular cleavage of a 170 amino acid cathelicidin antimicrobial peptide (47). However, to the knowledge of 
the authors, it has yet to be shown that the antigen processing and presentation machinery of the target cell is capable of generating an HLA class-I restriced peptide from the original protein. Without such confirmation, a role as autoantigen for CD8+ T-lymphocytes needs to be interpreted with care (48).

Finally, neolipid antigens generated by mast cell phospholipase have been described as targets for psoriatic CD1a restricted T-cells (49).

Besides autoreactive T-lymphocytes, $\mathrm{T}_{\text {regs }}$ are also thought to contribute to psoriasis through ineffective control of proinflammatory cells: while $\mathrm{CD} 4^{+} \mathrm{CD} 25^{+} \mathrm{FOXP} 3^{+}$cells are readily detectable in the blood of psoriasis patients, they are unable to suppress Th1 effects. In contrast, $\mathrm{T}_{\text {regs }}$ isolated from healthy individuals and co-cultured with Th1 cells from psoriasis patients were able to suppress biological effects of the latter (50). In line with this finding, a positive correlation between $\mathrm{T}_{\text {regs }}$ and Th17 cells (key effector cells in the context of the psoriatic inflammation) in psoriasis has been shown $(51,52)$ suggesting that the immune system attempts to downregulate the ongoing inflammation through increased presence of $\mathrm{T}_{\text {regs }}$, but these are unable to effectively inhibit the disease. As outlined in the introduction, there are at least four mechanisms of rendering $\mathrm{T}_{\text {regs }}$ dysfunctional.

\section{SCLERODERMA}

Scleroderma (Systemic Sclerosis, SSc) (53) (Table 1) occurs in around one in 10,000 people worldwide and has a remarkable female predominance. Although rare, scleroderma is associated with high mortality, greater than any other rheumatic disease. Clinical manifestations are heterogeneous, and progression may vary from somewhat stable situations to sometimes rapidly progressive disease. Cases of scleroderma are generally classified into one of two major subsets according to the extent of skin fibrosis: the limited form is defined by skin involvement distal from elbows and knees, whereas patients affected by the diffuse form present extensive cutaneous and internal organ involvement.

The pathophysiology of scleroderma includes three main peculiarities: progressive fibrosis, diffuse fibroproliferative microangiopathy, and inflammation. While the exact etiology remains unknown as of now, environmental as well as genetic factors are considered to be important in the initial phase of the disease. Several lines of evidence suggest that autoreactive T-cells and chronic inflammatory events participate in the initiation or maintenance of the fibrotic process (54).

The first hint comes from genetic and epigenetic studies. Loci in the HLA class II region show the strongest genetic association with the disease, followed by genes involved in B- and T-cell activation and innate immunity. Similarly, epigenetic alterations generally include genes with a role in autoimmunity and T-cell function or regulation (55).

Next, assessment of scleroderma skin revealed that a mononuclear cell infiltrate precedes the fibrotic change and that synthesis of collagen is maximal above it $(56,57)$. Interestingly, T-cells infiltrating the affected skin show a limited TCR usage, suggesting that they have undergone clonal expansion in response to a specific autoantigen (58).

Another aspect underlying the autoimmune nature of scleroderma is the characteristic presence of anti-nuclear antibodies, including anti-centromere, anti-topoisomerase 1 (anti-topo1) and anti-RNA polymerase III (RNApolIII) antibodies. Anti-topol antibodies have high specificity for scleroderma (20-40\% of patients) and predict more severe disease and mortality (59). Confirming the involvement of autoreactive $\mathrm{T}$ cell-dependent B-cell help, anti-topo1 antibodies are known to exhibit class switching and show strong associations with specific HLA alleles (60). Seminal works from Boin and Wright's groups proved that tolerance to topol antigens is effectively broken and topol-autoreactive T-cells are found in patients presenting these antibodies $(61,62)$. The possible pathogenic role of nucelar antibodies remains, however, debated, while the frequency of circulating autoreactive CD4+ T-cells was shown to predict interstitial-lung disease development (62).

Regarding the presence of autoantibodies, a striking feature is that patients having anti-RNApolIII antibodies but not the other types show a temporal clustering between the onset of cancer and scleroderma. Rosen et al. provided some evidence in favor of a causative link and proposed that somatic mutation of the RNApolIII in the tumor may actually trigger the activation of autoreactive T-cells that cross-react with the tumor mutated antigen, leading to the initiation of the autoimmune scleroderma response (63).

Finally, three randomized controlled trials tested the efficacy of autologous stem cell transplantation for treating scleroderma. A durable improvement in skin fibrosis, pulmonary functions and quality-of-life measures were achieved, suggesting that immune "replacement" and thus deletion of possible autoreactive lymphocytes might be beneficial (64).

While autoreactive T-cells likely represent an integral or causative part of the pathogenesis of scleroderma, the autoantigens and the mechanisms involved remain largely unknown.

Besides autoreactive T-cells, the quantification of $\mathrm{T}_{\text {regs }}$ in patient tissues generated contradictory results: most studies reported a reduced frequency while some found an increase in $\mathrm{T}_{\text {reg }}$ numbers, particularly in early and active disease. Nonetheless, $\mathrm{T}_{\text {regs }}$ appear to consistenly harbor a defective suppressing capacity in scleroderma, leading to a weaker peripheral tolerance $(65,66)$.

\section{BULLOUS PEMPHIGOID}

Bullous pemphigoid (BP) (67) (Table 1) develops in 12 to 66 individuals per million people per year. It is characterized by tense blisters and erosions, often preceded by urticarial lesions. Blisters often arise on the flexor sites of the extremities as well as the trunk; they may persist for several days before transforming into secondary lesions, namely erosions and crusts. 
Histopathology of lesional skin specimen shows subepidermal splitting, leaving the dermo-epidermal junction intact, and a dense infiltrate rich in granulocytes, primarily eosinophils and neutrophils.

Contrary to the entities discussed so far, BP is considered an antibody-mediated autoimmune disease. It is characterized by immunoglobulin (Ig) G and E autoantibodies recognizing BP230 and BP180, both antigens localizing to the hemidesmosomes. While BP230 represents an intracellular component, BP180 is a transmembrane glycoprotein of keratinocytes constituting the basal layer. The collagen type XVII extracellular NC16A domain of BP180 comprises immunodominant B-cell epitopes. Numerous in-vitro experiments as well as animal models have established a pivotal role for Fc receptor-mediated effects in the process of blister formation (68).

Repetitively, reports on a possible involvement of CD4+ helper T-lymphocytes were published $(69,70)$. However, while the key role of autoantibody responses to BP180 is wellestablished in BP, the evidence and clinical relevance of diseasespecific T-lymphocyte responses remained unclear. More recent work by Pickford et al. shed more light on the T-lymphocyte participation in BP autoreactivity (71). They tested proliferative and cytokine responses of peripheral blood mononuclear cells from patients and controls to recombinant NC16A and a panel of overlapping peptides spanning this region of BP180. They identified numerous disease-associated factors which influence the composition of the cytokine responses. The strongest association with BP was observed for specific IL-4 and IgE responses, suggesting a potential role for autoreactive Th2 lymphocytes. These results align well with older observations using a humanized mouse model, where the importance of NC16A specific Th-lymphocytes was demonstrated $(72,73)$. Interestingly, this $\mathrm{NC16A}$ response by T-lymphocytes was restricted to $\mathrm{HLA}-\mathrm{DQB} 1^{*} 0301$, a known $\mathrm{BP}$ susceptibility allele (74).

A role of $\mathrm{T}_{\text {regs }}$ in $\mathrm{BP}$ was recently documented by Haeberle et al. in a mouse model for BP: they showed that autoantibodies against different known autoantigens, including BP230, develop spontaneously in $\mathrm{T}_{\text {reg }}$ deficient scurfy mice, leading to blister formation. This study suggests that autoreactive Tlymphocytes initiate the disease in the absence of proper immune control (75).

\section{PEMPHIGUS VULGARIS}

Pemphigus vulgaris (PV) (76) is another blistering autoimmune disease with an immunopathogenesis comparable to pemphigoid. Its incidence is in the order of 1-5 new cases per million people per year. Clinically, PV often starts progressively with mucosal lesions and subsequently extensive flacid skin blisters. Blister formation occurs intraepidermally. Autoreactive IgG antibodies recognize desmoglein (Dsg) 3 and 1 within desmosomes, adhesion complexes between keratinocytes. HLA$\mathrm{DRB1}^{*}$ 04:02 and HLA-DQB1*05:03 have been identified as disease-associated HLA class II alleles.
Similar to BP, a role for autoreactive helper T-lymphocytes has long been postulated in PV, but was difficult to demonstrate. Several years ago, Emig et al. showed in a humanized HLA-DRB1*04:02 transgenic mouse model that T-lymphocytes recognize human desmoglein 3 epitopes in the context of HLA-DRB1*04:02 leading to the induction of pathogenic IgG autoantibodies, which in turn trigger intra-epidermal blister formation (77). Activation of Dsg3-reactive CD4+ Tlymphocytes is restricted to the HLA-DRB1*04:02 allele. IgG autoantibodies are produced following CD40-CD40L-dependent T-cell-B-cell interactions and exhibit specificities to both $\mathrm{N}$ and C-terminal epitopes of the human Dsg3 ectodomain. Since then, additional evidence has been generated for an active role of CD4+ helper T-lymphocytes (78), but functional studies in patients are still lacking, and most groups working in the field do not assign a high priority to this aspect of translational research in $\mathrm{PV}$ (79).

\section{ATOPIC DERMATITIS}

Atopic dermatitis (AD) (80) (Table 1) has a lifetime prevalence in the order of $10-20 \%$ in developed countries with pruritus being the leading symptom. Eczematous lesions can be acute, subacute or chronic, and predilection sites change with age. Co-occurrence of altered epidermal structure and function on the one hand and cutaneous inflammation triggered by pathologic immune responses to antigens encountered in the skin on the other hand are characteristic for AD.

Numerous cell types contribute to antigen presentation in $\mathrm{AD}$, including dermal dendritic cells, epidermal Langerhans cells, and inflamamtory dendritic epidermal cells expressing a highaffinity receptor for IgE (81). The latter explains how these cells can present allergens typically triggering type-I (immediate-type) allergic reactions, subsequently inducing T-lymphocyte mediated type-IV (delayed-type) reactions.

Autoreactivity is a known phenomenon in atopic dermatitis. A systematic review provided evidence that up to a third of patients exhibit autoreactive IgE antibodies (82). This may be based on molecular mimicry, as several IgEbinding keratinocyte-derived antigens show homology with environmental allergens (83). Besides, reports on autoreactive T-lymphocytes date back to the beginning of this decade $(84,85)$. Based on these observations, which suggested a role for the autoallergen Hom s 2, the $\alpha$-chain of the nascent polypeptide-associated complex ( $\alpha$-NAC), Roesner et al. performed an in-depth analysis of $\alpha$-NAC specific CD8+ T-cell responses (86). They found higher numbers of $\alpha$-NAC specific, terminally differentiated peripheral T-lymphocytes in sensitized atopic patients compared with non-atopic controls. These cells secrete IL-4 and IFN- $\gamma$, suggesting a pathogenic role in $\mathrm{AD}$.

As in psoriasis, there is also evidence for substantial dysregulation of $\mathrm{T}_{\text {regs }}$ in atopic dermatitis. The positive correlation of these cells with disease severity both in mouse models as well as in patients $(87,88)$ documents the immune 
TABLE 2 | Innovative therapeutic strategies exploring the role of T-lymphocytes.

\begin{tabular}{|c|c|c|c|}
\hline Target & approach & Evidence & References \\
\hline $\begin{array}{l}T_{\mathrm{RM}} \text { differentiation } \\
\text { and maintenance }\end{array}$ & JAK3 inhibition & $\begin{array}{l}\text { Clinically effective in } \\
\text { vitiligo, alopecia areata }\end{array}$ & $(23,94,95)$ \\
\hline $\begin{array}{l}T_{\mathrm{RM}} \text { differentiation } \\
\text { and maintenance }\end{array}$ & $\begin{array}{l}\text { Anti IL-15 } \\
\text { antibodies }\end{array}$ & $\begin{array}{l}\text { Effective in a mouse } \\
\text { model of vitiligo }\end{array}$ & (21) \\
\hline $\begin{array}{l}\text { Preventing Treg } \\
\text { transformation }\end{array}$ & Anti IL-23 & $\begin{array}{l}\text { Clinically effective in } \\
\text { psoriasis }\end{array}$ & (91) \\
\hline $\begin{array}{l}\text { Autoreactive } \\
\text { B-lymphocytes }\end{array}$ & $\begin{array}{l}\text { Chimeric antigen } \\
\text { receptor } \\
\text { T-lymphocytes }\end{array}$ & $\begin{array}{l}\text { Effective in a mouse } \\
\text { model of pemphigus } \\
\text { vulgaris }\end{array}$ & (96) \\
\hline $\begin{array}{l}\text { Immune } \\
\text { reconstitution }\end{array}$ & $\begin{array}{l}\text { Multiple } \\
\text { - Chemotherapies } \\
\text { - Depleting } \\
\text { antibodies } \\
\text { - AHSCT }\end{array}$ & $\begin{array}{l}\text { Clinically effective in } \\
\text { multiple sclerosis, } \\
\text { scleroderma }\end{array}$ & $(64,97,98)$ \\
\hline Treg expansion & mTOR inhibition & $\begin{array}{l}\text { Clinically effective in } \\
\text { lupus erythematosus, } \\
\text { psoriasis }\end{array}$ & $(99-101)$ \\
\hline
\end{tabular}

AHSCT, autologous hematopoietic stem cell transplantation.

system's attempt to downregulate the ongoing inflammation through increased presence of $\mathrm{T}_{\text {regs }}$, which, however, are unable to inhibit the disease.

\section{THERAPEUTIC PERSPECTIVES}

So far, we have reviewed the established or potential role of autoreactive T-lymphocytes in a number of different inflammatory skin diseases. These T-lymphocytes fall principally into two major categories: (1) they function either as effector cells or represent the immunological memory in the skin that may be responsible for relapsing disease or (2) they provide help to B-lymphocytes to produce the pathogenic autoantibodies, as is the case of BP and PV. In atopic dermatitis, there is evidence for both roles.

To date, targeted therapies such as biologics or small molecules allow to directly and specifically interfere with the central pathomechanisms. These therapies are often more effective when compared with conventional anti-inflammatory therapies, making these agents the key compounds of current treatment algorithms $(89,90)$. However, despite therapeutic effects, which sometimes go way beyond the respective molecules' half-lifes (91), all of these currently available therapies cannot prevent relapse, once they are stopped. Discussions to which extent such currently available therapies are disease-modifying, as we increasingly witness in the context of company-sponsored projects, e.g., in the field of psoriasis (92), seem therefore premature. Instead, remission might be a more appropriate term in this context.

As pointed out in the different chapters above, $\mathrm{T}_{\mathrm{RM}}$ are a particularly important subpopulation in the pathophysiology of several autoimmune skin diseases. Their presence elegantly explains recurrance of such diseases after seemingly successful therapy. This makes $\mathrm{T}_{\mathrm{RM}}$ attractive targets to achieve durable responses. Boniface and Senechal recently pointed out potential strategies in this regard, looking at vitiligo as a model for a skin memory disease (93) (Table 2):

- Strategies to prevent $\mathrm{T}_{\mathrm{RM}}$ differentiation and maintenance in the skin could target relevant mediators of this process, including IL-15, as discussed above. While effective depletion of skin-resident $\mathrm{T}_{\mathrm{RM}}$ through direct blockade of the IL-15 receptor has been shown in a mouse model (21), data from patients are not yet available. Another way to inhibit the IL15 signaling pathway is through inhibition of Janus Kinase 3 (JAK3). Noteworthy, a clinical trial demonstrated the efficacy of the non-specific JAK inhibitor tofacitinib in combination with phototherapy to treat vitiligo (95).

- Next, strategies to prevent accumulation of $\mathrm{T}_{\mathrm{RM}}$ in the skin might be warranted. As $\mathrm{T}_{\mathrm{RM}}$ are likely to accumulate after repetitive flares of the disease, maintenance therapies after successful initial disease control could be an adequate approach. In line with this hypothesis, maintenance therapy using a topical calcineurin inhibitor twice weekly in patients with repigmented lesions reduces the recurrance of old vitiligo lesions (16).

- Finally, while $\mathrm{T}_{\mathrm{RM}}$ depletion remains to be demonstrated in patients, it seems feasible to aim at dampening $\mathrm{T}_{\mathrm{RM}}$ activation through the long-term use of immunomodulating agents. In fact, both clinical studies cited above provide evidence for the efficacy of such an approach $(16,95)$. The study by Liu et al. assessed the effects of JAK inhibition and phototherapy separately, allowing for the conclusion that phototherapy seems necessary for melanocyte regeneration, while JAK inhibition suppresses T-cell mediators of vitiligo (95).

Noteworthy, the current pathogenetic concept of AA also suggests a role for memory T-lymphocytes, IFN- $\gamma$, and IL-15 (32). In that very publication, the authors went on to demonstrate therapeutic efficacy of the non-specific JAK inhibitor tofacitinib as well as the JAK1/2 inhibitor ruxolitinib not only in their mouse model, but also in all three AA patients treated with ruxolitinib (32). As in vitiligo, therapeutic application of JAK inhibitors is currently being explored further in AA (94).

Turning to bullous autoimmune diseases, engineering chimeric antigen receptor (CAR) T-lymphocytes may bear a potential (Table 2). This approach proved effective in leukemia, where a CD19-specific CAR, composed of an extracellular singlechain variable fragment antibody fused to cytoplasmic signaling domains, triggers cytotoxic T-cell reactions upon contact with CD19+ B-lymphocytes, which results in specific and permanent elimination of the respective B-lymphocytes, yielding durable remission (102). Ellebrecht et al. applied this concept to PV, suggesting that expression of Dsg3 as the extracellular domain of a CAR should specifically target cytotoxic responses to those B-lymphocytes bearing anti-Dsg3 B-cell receptors; this should result in a targeted therapy avoiding general immunosuppression (96). Using a mouse model, they succeeded to show that such cells expand, persist, and specifically eliminate Dsg3 autoreactive B-lymphocytes. 
While the strategies discussed so far document the substantial efforts to attack pro-inflammatory elements, much less studies assess the potential to strengthen regulatory elements. In this regard, recent observations in the field of psoriasis are of interest. A much cited hypothesis regards the IL-23/IL-17 axis as central in its pathogenesis, with IL-23 triggering the production of IL-17A in numerous cell types, mainly T-lymphocytes; IL-17A is itself a valid target for highly effective therapies $(34,103)$. As IL-23 inhibition exhibits long-lasting therapeutic efficacy way beyond the half-life of the biologics used (91), one might speculate that additional effects beyond the postulated "upstream" inhibition of IL-17A production might be clinically relevant. $\mathrm{T}_{\text {regs }}$ are potential targets in this regard. These lymphocytes exhibit substantial plasticity. They can lose their immunosuppressive function under the influence of pro-inflammatory cytokines such as IL-23, IL-1 $\beta$, and IL-2 through the loss of FOXP3, ultimately switching toward a pro-inflammatory function (104). IL-23 blockade may hamper this transformation. In line with this concept is the observation by Maxwell et al. who used a mouse model of colitis to show that a regulatory, anti-inflammatory environment in the gut can be promoted through blockade of IL-23 (105). Investigating the role of regulatory elements as potential therapeutic targets may deserve more attention in the future (10).

The "holy grail" of treating autoimmune diseases is the re-establishment of peripheral tolerance, may be best reflected by the concept of immune reconstitution therapy (Table 2). Multiple sclerosis has become a model disease in this regard. Numerous approaches have been explored in this disease to "reset" the immune system, including pulsed lympho- or myeloablative treatments through chemotherapies, monoclonal antibodies such as alemtuzumab, and autologous hematopoietic stem cell transplantation (AHSCT). The pivotal trial documenting feasibility of AHSCT in multiple sclerosis was published in 1997 (97). The current status of this field of research has recently been reviewed in this journal (98), supporting the concept of re-establishing a state of peripheral tolerance through deletion of pathogenic clones, achievable via direct ablation in combination with inducing lymphopenia, the latter favoring replicative senescence and clonal attrition. Normalization of genetic signatures along with altered regulatory $\mathrm{T}$-cell populations provide evidence that a restoration of the regulatory network of the immune system really takes place. Moreover, AHSCT is likely to initiate a "rebooting" of the intrathymic selection program that potentially results in the regeneration of a diversified repertoire of naïve $\mathrm{T}$-cells that will again be capable of appropriately modulating immune responses to future antigenic

\section{REFERENCES}

1. Koehli S, Naeher D, Galati-Fournier V, Zehn D, Palmer E. Optimal T-cell receptor affinity for inducing autoimmunity. Proc Natl Acad Sci USA. (2014) 111:17248-53. doi: 10.1073/pnas.1402724111

2. Eldershaw SA, Sansom DM, Narendran P. Expression and function of the autoimmune regulator (Aire) gene in non-thymic tissue. Clin Exp Immunol. (2011) 163:296-308. doi: 10.1111/j.1365-2249.2010.04316.x encounters. Similar observations have been made in the field of sceroderma (64).

An alternative approach is emerging in rheumatology, but could also be explored in the inflammatory skin diseases discussed above. This strategy is based on the role of the mechanistic target of rapamycin (mTOR) as a central regulator of T-cell lineage specification (106). Both mTOR complexes 1 (mTORC1) and 2 (mTORC2) need to be blocked simultaneously to allow $\mathrm{T}_{\text {reg }}$ differentiation. Studying systemic lupus erythematosus (SLE), Kato and Perl showed that IL-21, identified as a key proinflamamtory cytokine in this disease, stimulated both TORC-1 and-2, and abrogated differentiation as well as function of $\mathrm{T}_{\text {regs }}$ along with autophagy, a phenomenon underlying $\mathrm{T}_{\text {reg }}$ dysfunction in SLE (99). In turn, dual blockade of TORC- 1 and -2 by 4 weeks of rapamycin treatment induced autophagy and corrected $\mathrm{T}_{\text {reg }}$ function. Progressive improvement in disease activity, associated with a correction of pro-inflamamtory T-cell lineage specification was also observed in in patients with active SLE during 12 months of sirolimus treatment (100). This approach might have the potential to restore tolerance in other autoimmune diseases as well, including psoriasis (101).

In summary, it is evident that there are multiple pathways through which autoreactive T-lymphocytes contribute to the pathogenesis of inflammatory skin diseases, some of which have only recently been identified as classical autoimmune disorders. In all of these diseases, targeting the autoreactive T-cell subpopualtion is a promising and in some cases already wellestabilshed therapeutic strategy. $\mathrm{T}_{\mathrm{RM}}$ are particularly suitable targets to ensure long-lasting therapeutic effects; the same holds true for the strategies that strengthen the immunosuppressive functions of $\mathrm{T}_{\text {regs }}$. Observations in multiple sclerosis and scleroderma suggest that resetting the immune system in order to restore the state of tolerance as the ultimate goal in the management of autoimmunity at large may be feasible.

\section{AUTHOR CONTRIBUTIONS}

$\mathrm{W}$-HB and NB jointly selected the topic for the review, performed the literature review, wrote the manuscript, and designed the figure along with tables.

\section{FUNDING}

This work was supported by a grant from the Swiss National Science Foundation (310030_175470/1).
3. Richards DM, Kyewski B, Feuerer M. Re-examining the nature and function of self-reactive $\mathrm{T}$ cells. Trends Immunol. (2016) 37:114-25. doi: $10.1016 /$ j.it.2015.12.005

4. Mueller DL. Mechanisms maintaining peripheral tolerance. Nat Immunol. (2010) 11:21-7. doi: 10.1038/ni.1817

5. Shevach EM, Thornton AM. tTregs, pTregs, and iTregs: similarities and differences. Immunol Rev. (2014) 259:88-102. doi: 10.1111/imr. 12160 
6. Yu W, Jiang N, Ebert PJ, Kidd BA, Muller S, Lund PJ, et al. Clonal deletion prunes but does not eliminate self-specific alphabeta $\mathrm{CD} 8(+) \mathrm{T}$ lymphocytes. Immunity. (2015) 42:929-41. doi: 10.1016/j.immuni.2015.05.001

7. Richards DM, Ruggiero E, Hofer AC, Sefrin JP, Schmidt M, von Kalle $\mathrm{C}$, et al. The contained self-reactive peripheral $\mathrm{T}$ cell repertoire: size, diversity, and cellular composition. J Immunol. (2015) 195:2067-79. doi: 10.4049/jimmunol.1500880

8. Kong YC, Flynn JC. Opportunistic autoimmune disorders potentiated by immune-checkpoint inhibitors anti-CTLA-4 and anti-PD-1. Front Immunol. (2014) 5:206. doi: 10.3389/fimmu.2014.00206

9. Rosenblum MD, Remedios KA, Abbas AK. Mechanisms of human autoimmunity. J Clin Invest. (2015) 125:2228-33. doi: 10.1172/JCI78088

10. Uttarkar S, Brembilla NC, Boehncke WH. Regulatory cells in the skin: pathophysiological role and potential targets for antiinflammatory therapies. J Allergy Clin Immunol. (2019) 143:1302-10. doi: 10.1016/j.jaci.2018.12.1011

11. Boniface K, Seneschal J, Picardo M, Taieb A. Vitiligo: focus on clinical aspects, immunopathogenesis, and therapy. Clin Rev Allergy Immunol. (2018) 54:52-67. doi: 10.1007/s12016-017-8622-7

12. Yang $\mathrm{C}$, Wu J, Zhang $\mathrm{X}$, Wen L, Sun J, Cheng $\mathrm{Y}$, et al. Fine-mapping analysis of the MHC region for vitiligo based on a new Han-MHC reference panel. Gene. (2018) 648:76-81. doi: 10.1016/j.gene.2018.01.053

13. Yi X, Cui T, Li S, Yang Y, Chen J, Guo S, et al. Identification of the risk HLAA alleles and autoantigen in han chinese vitiligo patients and the association of CD8+T cell reactivity with disease characteristics. Med Sci Monit. (2018) 24:6489-97. doi: 10.12659/MSM.910515

14. van den Boorn JG, Konijnenberg D, Dellemijn TA, van der Veen JP, Bos JD, Melief CJ, et al. Autoimmune destruction of skin melanocytes by perilesional T cells from vitiligo patients. J Invest Dermatol. (2009) 129:222032. doi: $10.1038 /$ jid.2009.32

15. Taieb A, Alomar A, Bohm M, Dell'anna ML, De Pase A, Eleftheriadou $\mathrm{V}$, et al. Guidelines for the management of vitiligo: the European dermatology forum consensus. Br J Dermatol. (2013) 168:5-19. doi: $10.1111 / j .1365-2133.2012 .11197 . x$

16. Cavalie M, Ezzedine K, Fontas E, Montaudie H, Castela E, Bahadoran P, et al. Maintenance therapy of adult vitiligo with $0.1 \%$ tacrolimus ointment: a randomized, double blind, placebo-controlled study. J Invest Dermatol. (2015) 135:970-4. doi: 10.1038/jid.2014.527

17. Clark RA. Resident memory T cells in human health and disease. Sci Transl Med. (2015) 7:269rv261. doi: 10.1126/scitranslmed.3010641

18. Cheuk S, Schlums H, Gallais Serezal I, Martini E, Chiang SC, Marquardt $\mathrm{N}$, et al. CD49a Expression defines tissue-resident CD8(+) T cells poised for cytotoxic function in human skin. Immunity. (2017) 46:287-300. doi: 10.1016/j.immuni.2017.01.009

19. Malik BT, Byrne KT, Vella JL, Zhang P, Shabaneh TB, Steinberg SM, et al. Resident memory $\mathrm{T}$ cells in the skin mediate durable immunity to melanoma. Sci Immunol. (2017) 2:eaam6346. doi: 10.1126/sciimmunol.aam6346

20. Boniface K, Jacquemin C, Darrigade AS, Dessarthe B, Martins C, Boukhedouni N, et al. Vitiligo skin is imprinted with resident memory CD8 T cells expressing CXCR3. J Invest Dermatol. (2018) 138:355-64. doi: 10.1016/j.jid.2017.08.038

21. Richmond JM, Strassner JP, Zapata L Jr., Garg M, Riding RL, Refat MA, et al. Antibody blockade of IL-15 signaling has the potential to durably reverse vitiligo. Sci Transl Med. (2018) 10:eaam7710. doi: 10.1126/scitranslmed.aam7710

22. Trueb RM, Dias M. Alopecia areata: a comprehensive review of pathogenesis and management. Clin Rev Allergy Immunol. (2018) 54:68-87. doi: 10.1007/s12016-017-8620-9

23. Betz RC, Petukhova L, Ripke S, Huang H, Menelaou A, Redler S, et al. Genome-wide meta-analysis in alopecia areata resolves HLA associations and reveals two new susceptibility loci. Nat Commun. (2015) 6:5966. doi: 10.1038/ncomms6966

24. Goh C, Finkel M, Christos PJ, Sinha AA. Profile of 513 patients with alopecia areata: associations of disease subtypes with atopy, autoimmune disease and positive family history. J Eur Acad Dermatol Venereol. (2006) 20:1055-60. doi: 10.1111/j.1468-3083.2006.01676.x

25. Gordon KA, Tosti A. Alopecia: evaluation and treatment. Clin Cosmet Investig Dermatol. (2011) 4:101-6. doi: 10.2147/CCID.S10182
26. Barker CF, Billingham RE. Analysis of local anatomic factors that influence the survival times of pure epidermal and full-thickness skin homografts in guinea pigs. Ann Surg. (1972) 176:597-604. doi: 10.1097/00000658-197211000-00004

27. Reynolds AJ, Lawrence C, Cserhalmi-Friedman PB, Christiano AM, Jahoda CA. Trans-gender induction of hair follicles. Nature. (1999) 402:33-4. doi: $10.1038 / 46938$

28. Rajabi F, Drake LA, Senna MM, Rezaei N. Alopecia areata: a review of disease pathogenesis. Br J Dermatol. (2018) 179:1033-48. doi: 10.1111/bjd.16808

29. Gilhar A, Ullmann Y, Berkutzki T, Assy B, Kalish RS. Autoimmune hair loss (alopecia areata) transferred by T lymphocytes to human scalp explants on SCID mice. J Clin Invest. (1998) 101:62-7. doi: 10.1172/JCI551

30. Gilhar A, Landau M, Assy B, Shalaginov R, Serafimovich S, Kalish RS. Mediation of alopecia areata by cooperation between CD4+ and CD8+ T lymphocytes: transfer to human scalp explants on Prkdc(scid) mice. Arch Dermatol. (2002) 138:916-22. doi: 10.1001/archderm.138.7.916

31. Sundberg JP, Cordy WR, King LE Jr. Alopecia areata in aging C3H/HeJ mice. J Invest Dermatol. (1994) 102:847-56. doi: 10.1111/1523-1747.ep12382416

32. Xing L, Dai Z, Jabbari A, Cerise JE, Higgins CA, Gong W, et al. Alopecia areata is driven by cytotoxic T lymphocytes and is reversed by JAK inhibition. Nat Med. (2014) 20:1043-9. doi: 10.1038/nm.3645

33. Wang EHC, Yu M, Breitkopf T, Akhoundsadegh N, Wang X, Shi FT, et al. Identification of autoantigen epitopes in alopecia areata. J Invest Dermatol. (2016) 136:1617-26. doi: 10.1016/j.jid.2016.04.004

34. Boehncke WH, Schon MP. Psoriasis. Lancet. (2015) 386:983-94. doi: 10.1016/S0140-6736(14)61909-7

35. Boehncke WH, Dressel D, Zollner TM, Kaufmann R. Pulling the trigger on psoriasis. Nature. (1996) 379:777. doi: 10.1038/379777a0

36. Boyman O, Hefti HP, Conrad C, Nickoloff BJ, Suter M, Nestle FO. Spontaneous development of psoriasis in a new animal model shows an essential role for resident T cells and tumor necrosis factor-alpha. J Exp Med. (2004) 199:731-6. doi: 10.1084/jem.20031482

37. Bhushan M, Bleiker TO, Ballsdon AE, Allen MH, Sopwith $M$, Robinson MK, et al. Anti-E-selectin is ineffective in the treatment of psoriasis: a randomized trial. Br J Dermatol. (2002) 146:824-31. doi: 10.1046/j.1365-2133.2002.04743.x

38. Conrad C, Boyman O, Tonel G, Tun-Kyi A, Laggner U, de Fougerolles A, et al. Alphalbetal integrin is crucial for accumulation of epidermal $\mathrm{T}$ cells and the development of psoriasis. Nat Med. (2007) 13:836-42. doi: $10.1038 / \mathrm{nm} 1605$

39. Frampton JE, Plosker GL. Efalizumab: a review of its use in the management of chronic moderate-to-severe plaque psoriasis. Am J Clin Dermatol. (2009) 10:51-72. doi: 10.2165/0128071-200910010-00009

40. Schon MP, Zollner TM, Boehncke WH. The molecular basis of lymphocyte recruitment to the skin: clues for pathogenesis and selective therapies of inflammatory disorders. J Invest Dermatol. (2003) 121:951-62. doi: 10.1046/j.1523-1747.2003.12563.x

41. Gaide O, Emerson RO, Jiang X, Gulati N, Nizza S, Desmarais C, et al. Common clonal origin of central and resident memory $\mathrm{T}$ cells following skin immunization. Nat Med. (2015) 21:647-53. doi: 10.1038/nm.3860

42. Tiilikainen A, Lassus A, Karvonen J, Vartiainen P, Julin M. Psoriasis and HLA-Cw6. $\mathrm{Br} \quad J$ Dermatol. (1980) 102:179-84. doi: 10.1111/j.1365-2133.1980.tb05690.x

43. Schmitt-Egenolf M, Eiermann TH, Boehncke WH, Stander M, Sterry W. Familial juvenile onset psoriasis is associated with the human leukocyte antigen (HLA) class I side of the extended haplotype Cw6-B57-DRB1*0701DQA1*0201-DQB1*0303: a population- and family-based study. J Invest Dermatol. (1996) 106:711-4. doi: 10.1111/1523-1747.ep12345600

44. Menssen A, Trommler P, Vollmer S, Schendel D, Albert E, Gurtler L, et al. Evidence for an antigen-specific cellular immune response in skin lesions of patients with psoriasis vulgaris. J Immunol. (1995) 155:4078-83.

45. Lenz TL, Deutsch AJ, Han B, Hu X, Okada Y, Eyre S, et al. Widespread non-additive and interaction effects within HLA loci modulate the risk of autoimmune diseases. Nat Genet. (2015) 47:1085-90. doi: 10.1038/ ng. 3379

46. Arakawa A, Siewert K, Stohr J, Besgen P, Kim SM, Ruhl G, et al. Melanocyte antigen triggers autoimmunity in human psoriasis. J Exp Med. (2015) 212:2203-12. doi: 10.1084/jem.20151093 
47. Lande R, Botti E, Jandus C, Dojcinovic D, Fanelli G, Conrad C, et al. The antimicrobial peptide LL37 is a T-cell autoantigen in psoriasis. Nat Commun. (2014) 5:5621. doi: 10.1038/ncomms6621

48. Prinz JC. Human leukocyte antigen-class I alleles and the autoreactive $\mathrm{T}$ cell response in psoriasis pathogenesis. Front Immunol. (2018) 9:954. doi: 10.3389/fimmu.2018.00954

49. Cheung KL, Jarrett R, Subramaniam S, Salimi M, Gutowska-Owsiak D, Chen $\mathrm{YL}$, et al. Psoriatic T cells recognize neolipid antigens generated by mast cell phospholipase delivered by exosomes and presented by CD1a. J Exp Med. (2016) 213:2399-412. doi: 10.1084/jem.20160258

50. Bovenschen HJ, van de Kerkhof PC, van Erp PE, Woestenenk R, Joosten I, Koenen HJ. Foxp3 + regulatory T cells of psoriasis patients easily differentiate into IL-17A-producing cells and are found in lesional skin. J. Invest. Dermatol. (2011) 131:1853-60. doi: 10.1038/jid.2011.139

51. Ma L, Xue HB, Guan XH, Shu CM, Wang F, Zhang JH, et al. The imbalance of Th17 cells and CD4+CD25highFoxp3+ Treg cells in patients with atopic dermatitis. J Euro Acad Dermatol Venereol. (2013) 28:1079-86. doi: $10.1111 /$ jdv.12288

52. Zhang L, Li Y, Yang X, Wei J, Zhou S, Zhao Z, et al. Characterization of Th17 and FoxP3(+) treg cells in paediatric psoriasis patients. Scand J Immunol. (2016) 83:174-80. doi: 10.1111/sji.12404

53. Denton CP, Khanna D. Systemic sclerosis. Lancet. (2017) 390:1685-99. doi: 10.1016/S0140-6736(17)30933-9

54. Chizzolini C, Brembilla NC, Montanari E, Truchetet ME. Fibrosis and immune dysregulation in systemic sclerosis. Autoimmun Rev. (2011) 10:27681. doi: 10.1016/j.autrev.2010.09.016

55. Tsou PS, Sawalha AH. Unfolding the pathogenesis of scleroderma through genomics and epigenomics. J Autoimmun. (2017) 83:73-94. doi: 10.1016/j.jaut.2017.05.004

56. Kahari VM, Sandberg M, Kalimo H, Vuorio T, Vuorio E. Identification of fibroblasts responsible for increased collagen production in localized scleroderma by in situ hybridization. J Invest Dermatol. (1988) 90:664-70. doi: 10.1111/1523-1747.ep12560826

57. Prescott RJ, Freemont AJ, Jones CJ, Hoyland J, Fielding P. Sequential dermal microvascular and perivascular changes in the development of scleroderma. J Pathol. (1992) 166:255-63. doi: 10.1002/path.1711660307

58. Sakkas LI, Platsoucas CD. Is systemic sclerosis an antigen-driven T cell disease? Arthritis Rheum. (2004) 50:1721-33. doi: 10.1002/art.20315

59. Nihtyanova SI, Denton CP. Autoantibodies as predictive tools in systemic sclerosis. Nat Rev Rheumatol. (2010) 6:112-6. doi: 10.1038/nrrheum.2009.238

60. Kuwana M, Medsger TA Jr., Wright TM. T cell proliferative response induced by DNA topoisomerase I in patients with systemic sclerosis and healthy donors. J Clin Invest. (1995) 96:586-96. doi: 10.1172/JCI118071

61. Kuwana M, Medsger TA Jr., Wright TM. Analysis of soluble and cell surface factors regulating anti-DNA topoisomerase I autoantibody production demonstrates synergy between Th1 and Th2 autoreactive T cells. J Immunol. (2000) 164:6138-46. doi: 10.4049/jimmunol.164.12.6138

62. Fava A, Cimbro R, Wigley FM, Liu QR, Rosen A, Boin F. Frequency of circulating topoisomerase-I-specific CD4 T cells predicts presence and progression of interstitial lung disease in scleroderma. Arthritis Res Ther. (2016) 18:99. doi: 10.1186/s13075-016-0993-2

63. Joseph CG, Darrah E, Shah AA, Skora AD, Casciola-Rosen LA, Wigley FM, et al. Association of the autoimmune disease scleroderma with an immunologic response to cancer. Science. (2014) 343:152-7. doi: 10.1126/science.1246886

64. Del Papa N, Pignataro F, Zaccara E, Maglione W, Minniti A. Autologous hematopoietic stem cell transplantation for treatment of systemic sclerosis. Front Immunol. (2018) 9:2390. doi: 10.3389/fimmu.2018.02390

65. Brembilla NC, Chizzolini C. T cell abnormalities in systemic sclerosis with a focus on Th17 cells. Eur Cytokine Netw. (2012) 23:128-39. doi: 10.1684/ecn.2013.0325

66. Frantz C, Auffray C, Avouac J, Allanore Y. Regulatory T cells in systemic sclerosis. Front Immunol. (2018) 9:2356. doi: 10.3389/fimmu.2018.02356

67. Schmidt E, Zillikens D. Pemphigoid diseases. Lancet. (2013) 381:320-32. doi: 10.1016/S0140-6736(12)61140-4

68. Liu Z, Diaz LA, Troy JL, Taylor AF, Emery DJ, Fairley JA, et al. A passive transfer model of the organ-specific autoimmune disease, bullous pemphigoid, using antibodies generated against the hemidesmosomal antigen, BP180. J Clin Invest. (1993) 92:2480-8. doi: 10.1172/JCI1 16856

69. Eming R, Budinger L, Riechers R, Christensen O, Bohlen H, Kalish R, et al. Frequency analysis of autoreactive T-helper 1 and 2 cells in bullous pemphigoid and pemphigus vulgaris by enzyme-linked immunospot assay. Br J Dermatol. (2000) 143:1279-82. doi: 10.1046/j.1365-2133.2000.03901.x

70. Lin MS, Fu CL, Giudice GJ, Olague-Marchan M, Lazaro AM, Stastny P, et al. Epitopes targeted by bullous pemphigoid $\mathrm{T}$ lymphocytes and autoantibodies map to the same sites on the bullous pemphigoid 180 ectodomain. J Invest Dermatol. (2000) 115:955-61. doi: 10.1046/j.1523-1747.2000.00153.x

71. Pickford WJ, Gudi V, Haggart AM, Lewis BJ, Herriot R, Barker RN, et al. T cell participation in autoreactivity to NC16a epitopes in bullous pemphigoid. Clin Exp Immunol. (2015) 180:189-200. doi: 10.1111/cei.12566

72. Budinger L, Borradori L, Yee C, Eming R, Ferencik S, Grosse-Wilde H, et al. Identification and characterization of autoreactive $\mathrm{T}$ cell responses to bullous pemphigoid antigen 2 in patients and healthy controls. J Clin Invest. (1998) 102:2082-9. doi: 10.1172/JCI3335

73. Thoma-Uszynski S, Uter W, Schwietzke S, Schuler G, Borradori L, Hertl M. Autoreactive T and B cells from bullous pemphigoid (BP) patients recognize epitopes clustered in distinct regions of BP180 and BP230. J Immunol. (2006) 176:2015-23. doi: 10.4049/jimmunol.176.3.2015

74. Delgado JC, Turbay D, Yunis EJ, Yunis JJ, Morton ED, Bhol K, et al. A common major histocompatibility complex class II allele HLA-DQB1* 0301 is present in clinical variants of pemphigoid. Proc Natl Acad Sci USA. (1996) 93:8569-71. doi: 10.1073/pnas.93.16.8569

75. Haeberle S, Wei X, Bieber K, Goletz S, Ludwig RJ, Schmidt E, et al. Regulatory T-cell deficiency leads to pathogenic bullous pemphigoid antigen 230 autoantibody and autoimmune bullous disease. J. Allergy Clin. Immunol. (2018) 142:1831-1842.e1837. doi: 10.1016/j.jaci.2018.04.006

76. Bystryn JC, Rudolph JL. Pemphigus. Lancet. (2005) 366:61-73. doi: 10.1016/S0140-6736(05)66829-8

77. Eming R, Hennerici T, Backlund J, Feliciani C, Visconti KC, Willenborg S, et al. Pathogenic IgG antibodies against desmoglein 3 in pemphigus vulgaris are regulated by HLA-DRB1*04:02-restricted T cells. J Immunol. (2014) 193:4391-9. doi: 10.4049/jimmunol.1401081

78. Sezin T, Vorobyev A, Sadik CD, Zillikens D, Gupta Y, Ludwig RJ. Gene expression analysis reveals novel shared gene signatures and candidate molecular mechanisms between pemphigus and systemic lupus erythematosus in CD4(+) T Cells. Front Immunol. (2017) 8:1992. doi: 10.3389/fimmu.2017.01992

79. Spindler V, Eming R, Schmidt E, Amagai M, Grando S, Jonkman MF, et al. Mechanisms causing loss of keratinocyte cohesion in pemphigus. J Invest Dermatol. (2018) 138:32-7. doi: 10.1016/j.jid.2017.06.022

80. Weidinger S, Novak N. Atopic dermatitis. Lancet. (2016) 387:1109-22. doi: 10.1016/S0140-6736(15)00149-X

81. Novak N. An update on the role of human dendritic cells in patients with atopic dermatitis. J Allergy Clin Immunol. (2012) 129:879-86. doi: 10.1016/j.jaci.2012.01.062

82. Tang TS, Bieber T, Williams HC. Does "autoreactivity" play a role in atopic dermatitis? J. Allergy Clin. Immunol. (2012) 129:1209-15.e1202. doi: 10.1016/j.jaci.2012.02.002

83. Zeller S, Rhyner C, Meyer N, Schmid-Grendelmeier P, Akdis CA, Crameri R. Exploring the repertoire of IgE-binding self-antigens associated with atopic eczema. J Allergy Clin Immunol. (2009) 124:278-85, 285.e271-7. doi: 10.1016/j.jaci.2009.05.015

84. Balaji H, Heratizadeh A, Wichmann K, Niebuhr M, Crameri R, Scheynius A, et al. Malassezia sympodialis thioredoxin-specific T cells are highly crossreactive to human thioredoxin in atopic dermatitis. J. Allergy Clin. Immunol. (2011) 128:92-9 e94. doi: 10.1016/j.jaci.2011.02.043

85. Heratizadeh A, Mittermann I, Balaji H, Wichmann K, Niebuhr M, Valenta $\mathrm{R}$, et al. The role of $\mathrm{T}$-cell reactivity towards the autoantigen alpha-NAC in atopic dermatitis. Br J Dermatol. (2011) 164:316-24. doi: 10.1111/j.1365-2133.2010.10090.x

86. Roesner LM, Heratizadeh A, Wieschowski S, Mittermann I, Valenta R, Eiz-Vesper B, et al. alpha-NAC-specific autoreactive CD8+ T cells in atopic dermatitis are of an effector memory type and secrete IL-4 and IFN-gamma. J Immunol. (2016) 196:3245-52. doi: 10.4049/jimmunol.15 00351 
87. Gaspar K, Barath S, Nagy G, Mocsai G, Gyimesi E, Szodoray P, et al. Regulatory T-cell subsets with acquired functional impairment: important indicators of disease severity in atopic dermatitis. Acta Derm Venereol. (2015) 95:151-5. doi: 10.2340/00015555-1882

88. Roesner LM, Floess S, Witte T, Olek S, Huehn J, Werfel T. Foxp3(+) regulatory $\mathrm{T}$ cells are expanded in severe atopic dermatitis patients. Allergy. (2015) 70:1656-60. doi: 10.1111/all.12712

89. Feliciani C, Joly P, Jonkman MF, Zambruno G, Zillikens D, Ioannides D, et al. Management of bullous pemphigoid: the European dermatology forum consensus in collaboration with the European academy of dermatology and venereology. Br J Dermatol. (2015) 172:867-77. doi: 10.1111/bjd. 13717

90. Nast A, Amelunxen L, Augustin M, Boehncke WH, Dressler C, Gaskins M, et al. S3 Guideline for the treatment of psoriasis vulgaris, update - short version part 2 - special patient populations and treatment situations. J Dtsch Dermatol Ges. (2018) 16:806-13. doi: 10.1111/ddg.13538

91. Krueger JG, Ferris LK, Menter A, Wagner F, White A, Visvanathan S, et al. Anti-IL-23A mAb BI 655066 for treatment of moderate-to-severe psoriasis: Safety, efficacy, pharmacokinetics, and biomarker results of a single-risingdose, randomized, double-blind, placebo-controlled trial. J. Allergy Clin. Immunol. (2015) 136:116-24.e117. doi: 10.1016/j.jaci.2015.01.018

92. Iversen L, Eidsmo L, Austad J, de Rie M, Osmancevic A, Skov L, et al. Secukinumab treatment in new-onset psoriasis: aiming to understand the potential for disease modification - rationale and design of the randomized, multicenter STEPIn study. J Eur Acad Dermatol Venereol. (2018) 32:1930-9. doi: $10.1111 /$ jdv.14979

93. Boniface K, Seneschal J. Vitiligo as a skin memory disease: The need for early intervention with immunomodulating agents and a maintenance therapy to target resident memory T cells. Exp Dermatol. (2019). doi: 10.1111/exd.13879. [Epub ahead of print].

94. Damsky W, King BA. JAK inhibitors in dermatology: the promise of a new drug class. J Am Acad Dermatol. (2017) 76:736-44. doi: 10.1016/j.jaad.2016.12.005

95. Liu LY, Strassner JP, Refat MA, Harris JE, King BA. Repigmentation in vitiligo using the Janus kinase inhibitor tofacitinib may require concomitant light exposure. J. Am. Acad. Dermatol. (2017) 77:675-82.e671. doi: 10.1016/j.jaad.2017.05.043

96. Ellebrecht CT, Bhoj VG, Nace A, Choi EJ, Mao X, Cho MJ, et al. Reengineering chimeric antigen receptor $\mathrm{T}$ cells for targeted therapy of autoimmune disease. Science. (2016) 353:179-84. doi: 10.1126/science.aaf6756

97. Fassas A, Anagnostopoulos A, Kazis A, Kapinas K, Sakellari I, Kimiskidis V, et al. Peripheral blood stem cell transplantation in the treatment of progressive multiple sclerosis: first results of a pilot study. Bone Marrow Transplant. (1997) 20:631-8. doi: 10.1038/sj.bmt. 1700944
98. Massey JC, Sutton IJ, Ma DDF, Moore JJ. Regenerating immunotolerance in multiple sclerosis with autologous hematopoietic stem cell transplant. Front Immunol. (2018) 9:410. doi: 10.3389/fimmu.2018.00410

99. Kato H, Perl A. Blockade of treg cell differentiation and function by the interleukin-21-mechanistic target of rapamycin axis via suppression of autophagy in patients with systemic lupus erythematosus. Arthritis Rheumatol. (2018) 70:427-38. doi: 10.1002/art.40380

100. Lai ZW, Kelly R, Winans T, Marchena I, Shadakshari A, Yu J, et al. Sirolimus in patients with clinically active systemic lupus erythematosus resistant to, or intolerant of, conventional medications: a single-arm, open-label, phase 1/2 trial. Lancet. (2018) 391:1186-96. doi: 10.1016/S0140-6736(18) 30485-9

101. Leducq S, Giraudeau B, Tavernier E, Maruani A. Topical use of mammalian target of rapamycin inhibitors in dermatology: a systematic review with meta-analysis. J Am Acad Dermatol. (2019) 80:735-42. doi: 10.1016/j.jaad.2018.10.070

102. Schuster SJ, Svoboda J, Chong EA, Nasta SD, Mato AR, Anak O, et al. Chimeric antigen receptor T cells in refractory B-cell lymphomas. $N$ Engl J Med. (2017) 377:2545-54. doi: 10.1056/NEJMoa1708566

103. Hawkes JE, Chan TC, Krueger JG. Psoriasis pathogenesis and the development of novel targeted immune therapies. J Allergy Clin Immunol. (2017) 140:645-53. doi: 10.1016/j.jaci.2017. 07.004

104. Kannan AK, Su Z, Gauvin DM, Lippert SE, Marie HP, McGaraughty SP, et al. IL-23 induces regulatory $\mathrm{T}$ cell plasticity with implications for inflammatory skin diseases. J. Immunol. (2017) 198(1 Suppl):220. 213-20.213.

105. Maxwell JR, Zhang Y, Brown WA, Smith CL, Byrne FR, Fiorino $\mathrm{M}$, et al. Differential roles for Interleukin-23 and Interleukin17 in Intestinal Immunoregulation. Immunity. (2015) 43:739-50. doi: 10.1016/j.immuni.2015.08.019

106. Delgoffe GM, Pollizzi KN, Waickman AT, Heikamp E, Meyers DJ, Horton $\mathrm{MR}$, et al. The kinase mTOR regulates the differentiation of helper $\mathrm{T}$ cells through the selective activation of signaling by mTORC1 and mTORC2. Nat Immunol. (2011) 12:295-303. doi: 10.1038/ni.2005

Conflict of Interest Statement: The authors declare that the research was conducted in the absence of any commercial or financial relationships that could be construed as a potential conflict of interest.

Copyright (C) 2019 Boehncke and Brembilla. This is an open-access article distributed under the terms of the Creative Commons Attribution License (CC BY). The use, distribution or reproduction in other forums is permitted, provided the original author(s) and the copyright owner(s) are credited and that the original publication in this journal is cited, in accordance with accepted academic practice. No use, distribution or reproduction is permitted which does not comply with these terms. 